\title{
Current Status of Research, Regulations, and Future Challenges for CRISPR Gene Editing in Crop Improvement ${ }^{1}$
}

\author{
Sadikshya Sharma, Heqiang Huo, and Seonghee Lee ${ }^{2}$
}

\section{Introduction}

Plant breeders and researchers have sought to improve crops since the dawn of agriculture. For hundreds of years, conventional breeding has had a tremendous impact on agricultural productivity. Over the last few decades, researchers have begun to transfer DNA between species in what is known as genetic engineering (transgenic technology). Recently, new plant-breeding technology such as CRISPR gene editing has provided the potential to substantially improve crop breeding in agriculture. Considerable efforts have been devoted to apply this gene-editing technology in modern agriculture to increase crop yields and improve the quality of food ingredients, especially by many of the major agronomic seed-producing companies. In this article, we outline the recent research updates and regulations on gene editing in crop improvement. The target audience for this report is the general public, including both scientists and nonscientists.

\section{How does CRISPR gene-editing technology improve crops and benefit the public?}

Using the CRISPR gene-editing technique, researchers can selectively "edit" plant genomes to obtain desired traits. Gene editing is occasionally confused with the transgenic approach (colloquially referred to as "GMO") and referred to as the same idea. Schneider et al. (2014) describe clearly what genetically modified (GM) foods or genetically modified organisms (GMO) are as well as other possible benefits of crop improvement. In other EDIS articles (Lee et al. 2016, 2018), we have also described what gene-editing techniques are, how they differ from transgenic approaches, and their potential applications for cultivated strawberries.

CRISPR gene-editing technology has been applied to various crops to increase yield, disease resistance, and nutritional quality. These crops include wheat, tomato, banana, rice, cassava, cucumber, grape, apple, citrus, canola, and corn. For example, to increase yield, tomatoes with double the number of branches were created by Lippman and colleagues at Cold Spring Harbor Laboratory (Rodríguez-Leal et al. 2017; Rothan et al. 2019). Besides yield, gene editing in tomatoes can create enhanced nutritional quality and biotic and abiotic stress resistance, which would otherwise take decades to achieve through traditional breeding (Krishna et al. 2019). Huanglongbing (HLB), or citrus greening, is a devastating disease of citrus worldwide, and in Florida it has reduced citrus production by more than $50 \%$. There is currently no genetic resistance source available for HLB-resistance breeding (Khachatryan and Choi 2017; Dodds, Gorham, and Rumble, 2017; Ledford 2017), but Dr. Nian Wang's group at UF/IFAS has

1. This document is HS1334, one of a series of the Horticultural Sciences Department, UF/IFAS Extension. Original publication date August 2019. Visit the EDIS website at https://edis.ifas.ufl.edu for the currently supported version of this publication.

2. Sadikshya Sharma, OPS, UF/IFAS Gulf Coast Research and Education Center; Heqiang Huo, assistant professor, Environmental Horticulture Department UF/IFAS Mid-Florida REC; and Seonghee Lee, assistant professor, Horticultural Sciences Department, UF/IFAS GCREC; UF/IFAS Extension, Gainesville, FL 32611.

The Institute of Food and Agricultural Sciences (IFAS) is an Equal Opportunity Institution authorized to provide research, educational information and other services

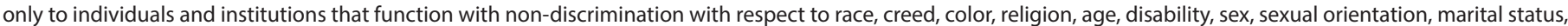

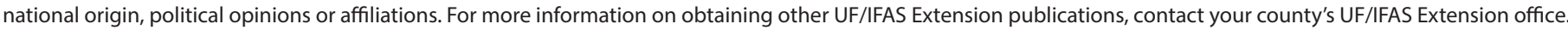
U.S. Department of Agriculture, UF/IFAS Extension Service, University of Florida, IFAS, Florida A \& M University Cooperative Extension Program, and Boards of County Commissioners Cooperating. Nick T. Place, dean for UF/IFAS Extension. 
begun to generate greening-resistant citrus varieties using CRISPR-based gene editing, which could potentially save the Florida citrus industry.

Some important quality concerns in various foods can also be improved using gene-editing technology. For example, reduced-gluten wheat, nonbrowning mushrooms and apples, and soybeans with reduced unhealthy saturated fats can be obtained using CRISPR gene-editing tools (Waltz, 2016; Jacobs et al. 2015; Sánchez-León, et al. 2017). Table 1 lists the agricultural companies that are currently using CRISPR gene-editing techniques to improve crops.

\section{What CRISPR gene-edited foods are available in grocery stores?}

Gene-edited soybean oil, cold-storable potatoes, high-fiber and gluten-reduced wheat, and lower-saturated-fat canola have been developed by Calyxt (formerly Cellectis Plant Sciences, Inc., New Brighton, MN). Gene-edited soybean oil went on the US market in 2019, and gene-edited nonbrowning button mushrooms are expected to be on the market soon. A gene-edited herbicide-resistant canola (SU Canola + Draft herbicide growing system), developed by Cibus, is being cultivated in fields in North Dakota and Montana as of 2019. Moreover, Cibus plans to release herbicide-tolerant flax in the United States in 2020. The Cibus pipeline also includes herbicide-tolerant rice and late blight-resistant potatoes. Flax with increased omega-3 content is currently being developed by Yield10Bioscience, and cacao with resistance to fungal and viral diseases at the Innovative Genomics Institute at Berkeley. In addition, the company Pairwise has a plan to use gene editing to produce sweeter strawberries with better shelf storage by 2024 .

Corteva plans to release waxy corn hybrids developed using gene-editing techniques in 2019 or 2020.

\section{Current Regulations and Policies for CRISPR Gene-Edited Crops}

With the advent of recombinant DNA in the 1980s, the Coordinated Framework for Regulation of Biotechnology was issued by the White House Office of Science and Technology Policy. Three Federal agencies, the Environmental Protection Agency (EPA), the USDA, and the Food and Drug Administration (FDA), were charged with the implementation of laws regulating biotechnology products. The EPA mainly regulates bioengineered products intended for pesticidal purposes, biofertilizers, bioremediation, and the production of various industrial compounds, including biofuels. As such, the EPA will not regulate
CRISPR-edited plants as long as the altered traits are not for synthesis of toxic chemicals like pesticides or biofuels. The USDA's Animal and Plant Health Inspection Service (APHIS) authorizes the importation, interstate movement, and environmental release of plants that pose a plant pest risk. The FDA focuses on the safe regulation of genetically engineered foods that can be used for dietary supplements, cosmetics, drugs, and medical devices. The FDA ensures food products comply with legal requirements, regardless of their production methods (whether traditional or gene-edited).

Research on the CRISPR-Cas9 system for gene editing is done worldwide, but there is no internationally agreedupon regulatory policy for gene-edited products. In the United States, the USDA, FDA, and EPA have taken different steps toward regulating agricultural products produced by new plant-breeding technologies, including CRISPR gene editing. As early as 2016, the USDA approved a CRISPR-edited mushroom that was altered for antibrowning and an improved waxy corn variety created with CRISPR-Cas9 from DuPont/Pioneer. The USDA emphasizes that these gene-edited crops do not include DNA from other plant species, animals, or bacteria; thus, they should not be considered transgenic. On March 28, 2018, USDA secretary Sonny Perdue issued a formal statement on innovative plant-breeding techniques (including CRISPR gene editing). The statement clarified that the USDA does not have plans to evaluate gene-edited plants for health and environmental safety if they could otherwise have been developed through traditional breeding, unless these geneedited plants are potential plant pests or developed using plant pests. The EPA requires virtually no assessment of the environmental impact of gene-edited organisms. The FDA has no additional requirement for the food safety assessment of gene-edited crops. However, the FDA will regulate gene-editing used in animals as "new animal drugs."

In contrast to the United States, the European Court of Justice has ruled that gene-editing techniques fall within the European Union's 2001 GMO directive, meaning that geneedited products should be treated like traditional transgenic products (Faure and Napier 2018) and be subjected to a mandatory risk assessment (Callaway 2018). According to Faure and Napier, CRISPR gene-editing technology will not be profitable in the European Union and is unlikely to be implemented in the near future. Several scientists in Europe together with the European Commission's top scientific advisory panel have sharply rebuked both the European Court decision on gene editing and Europe's entire framework 
for regulating genetically modified organisms (https://agfundernews.com/europes-gene-editing-regulation-exposesthe-messy-relationship-between-science-and-politics. html; https://allianceforscience.cornell.edu/blog/2018/11/ top-science-panel-criticizes-eus-gmo-regulations/). Gene editing is also currently considered GM in New Zealand and controlled by the Environmental Protection Authority (EPA).

Reports on the potential advantages and disadvantages of gene editing have been issued at several domestic and international meetings hosted by the US National Academy of Sciences. The Office of the Director of National Intelligence included gene editing in the World Threat Assessment reports submitted to Congress in 2016 and 2017. Japan announced that gene-edited foods should not be regulated in the same way as transgenic foods if the techniques involved meet certain criteria (Normile 2019). For many countries, a clear regulatory policy has not yet been developed for gene-edited crops.

\section{Conclusion}

Gene-editing techniques like CRISPR and TALEN are fundamental breakthroughs in plant genetic improvement that can adjust desired traits more quickly and precisely than traditional breeding. In recent years, it has been applied in many crop systems to improve important agronomic traits such as yield, nutritional value, and disease resistance. However, there still seems to be widespread public concern and regulatory uncertainty over food ingredients from gene-edited crops. Nevertheless, such foods will soon be available on supermarket shelves, and therefore it is important that the regulatory status of gene-edited foods is clarified and that consumers are adequately informed about the new technology.

\section{References}

Callaway, E. 2018. "CRISPR plants now subject to tough GM laws in European Union.” Nature 560(7716): 16.

Dodds, N. M. W., L. M. Gorham, and J. N. Rumble. 2017. Floridians' Perceptions of GMOs: GMOs and Florida Citrus. AEC520. Gainesville: University of Florida Institute of Food and Agricultural Sciences. http://edis.ifas.ufl.edu/wc182.

Faure, J-D., and J. A. Napier. 2018. "Europe's first and last field trial of gene-edited plants?” eLife 7: e42379.

Funk, C., and B. Kennedy. 2016. “The new food fights: U.S. public divides over food science.” 2016. Pew Research
Center. https://www.pewresearch.org/science/2016/12/01/ the-new-food-fights/

Jacobs, T. B., et al. 2015. "Targeted genome modifications in soybean with CRISPR/Cas9.” BMC Biotechnology 15: 16.

Khachatryan, H., and H. J. Choi. 2017. Factors Affecting Consumer Preferences and Demand for Ornamental Plants. FE938. Gainesville: University of Florida Institute of Food and Agricultural Sciences. http://edis.ifas.ufl.edu/fe938.

Krishna, R., et al. 2019. "Transgenic tomatoes for abiotic stress tolerance: status and way ahead." 3 Biotech 9:143.

Ledford, H. 2017. "Engineered virus in line to battle citrus disease.” Nature 545: 277.

Lee, S., Y-H. Noh, S. Verma, and V. M. Whitaker. 2016. DNA, Technology, and Florida Strawberries. HS1287. Gainesville: University of Florida Institute of Food and Agricultural Sciences. http://edis.ifas.ufl.edu/hs1287.

Lee, S., C. Yoo, K. Folta, and V. M. Whitaker. 2018. CRISPR Gene Editing in Strawberry. HS1315. Gainesville: University of Florida Institute of Food and Agricultural Sciences. http://edis.ifas.ufl.edu/hs1315.

Normile, D. 2019. "Gene-edited foods are safe, Japanese panel concludes.” https:// www.sciencemag.org/news/2019/03/ gene-edited-foods-are-safe-japanese-panel-concludes.

Rodríguez-Leal, D., et al. 2017. "Engineering Quantitative Trait Variation for Crop Improvement by Genome Editing." Cell 171(2): 470-480.

Rothan, C., et al. 2019. "Trait discovery and editing in tomato." Plant J. 97(1): 73-90.

Sánchez-León, S., et al. 2017. "Low-gluten, nontransgenic wheat engineered with CRISPR/Cas9.” Plant Biotechnol J. 16(4): 902-910.

Schneider, K., R. Goodrich Schneider, and S. Richardson. 2014. Genetically Modified Food. FSHN02-2. Gainesville: University of Florida Institute of Food and Agricultural Sciences. http://edis.ifas.ufl.edu/fs084

Waltz, E. 2016. “Gene-edited CRISPR mushroom escapes US regulation.” Nature News 532(7599): 293. 
Table 1. A selection of companies using CRISPR gene editing for crop improvement.

\begin{tabular}{|l|l|}
\hline \multicolumn{1}{|c|}{ Company } & \multicolumn{1}{c|}{ Targeted gene-editing crops } \\
\hline Syngenta & Corn, soybean, wheat, tomato, and sunflower for yield. \\
\hline Benson Hill Biosystems & Row crops for yield, disease resistance, and herbicide tolerance. \\
\hline Yield10 Bioscience & Camelina for higher oil content. \\
\hline Tropic Biosciences & Banana and coffee. \\
\hline Pairwise & Corn, soybean, fruits and vegetables. \\
\hline Corteva & Corn. \\
\hline
\end{tabular}

Table 2. CRISPR-modified foods still in development and already approved for the market.

\begin{tabular}{|c|c|c|c|}
\hline Crop & Purpose of gene-editing & Country & Current stage \\
\hline Groundcherry tomato & Improve productivity & United States & $\begin{array}{l}\text { Research completed-plant will be ready for } \\
\text { market }\end{array}$ \\
\hline Tomato & $\begin{array}{l}\text { Increase size and yield } \\
\text { Improve lycopene accumulation }\end{array}$ & European Union & Research completed-in field-trial stage \\
\hline $\begin{array}{l}\text { White button } \\
\text { mushrooms }\end{array}$ & Prevent browning & United States & $\begin{array}{l}\text { Ready for market-awaiting Food and Drug } \\
\text { Administration approval }\end{array}$ \\
\hline Rice & Improve yield & China & Research continuing on additional varieties \\
\hline Citrus & $\begin{array}{l}\text { Citrus greening disease } \\
\text { resistance }\end{array}$ & United States & Currently being researched \\
\hline Cacao & $\begin{array}{l}\text { Enhance resistance to } \\
\text { Phytophthora tropicalis disease }\end{array}$ & United States & Proof of concept achieved \\
\hline Wheat & Reduce gluten content & European Union & Research completed-in field-trial stage \\
\hline Apple & Nonbrowning & & In stores \\
\hline $\begin{array}{l}\text { Soybean } \\
\text { Wheat } \\
\text { Alfalfa } \\
\text { Potato }\end{array}$ & $\begin{array}{l}\text { High oleic acid, less saturated } \\
\text { fat } \\
\text { High fiber } \\
\text { Improve quality } \\
\text { Cold storage, reduced browning }\end{array}$ & Calyxt, United States & $\begin{array}{l}\text { Commercial pilot test } \\
\text { Phase II } \\
\text { Phase II } \\
\text { Phase II }\end{array}$ \\
\hline Corn & Waxy corn & Corteva, United States & Research completed-in field-trial stage \\
\hline Camelina & Increase oil content & $\begin{array}{l}\text { Yield10 Bioscience, United } \\
\text { States }\end{array}$ & Research completed-in field-trial stage \\
\hline
\end{tabular}

